\title{
An unknown oxidative metabolism substantially contributes to soil $\mathrm{CO}_{2}$ emissions
}

\author{
V. Maire ${ }^{1, *}$, G. Alvarez ${ }^{1,2}$, J. Colombet ${ }^{3}$, A. Comby ${ }^{1}$, R. Despinasse ${ }^{4}$, E. Dubreucq ${ }^{5}$, M. Joly ${ }^{1}$, A.-C. Lehours ${ }^{3}$, \\ V. Perrier ${ }^{5}$, T. Shahzad ${ }^{1, * *}$, and S. Fontaine ${ }^{1}$ \\ ${ }^{1}$ INRA, UR 874 UREP, 63100 Clermont-Ferrand, France \\ ${ }^{2}$ Clermont Université, VetAgro Sup, 63000, Clermont-Ferrand, France \\ ${ }^{3}$ University of Clermont Ferrand, UMR 6023 LMGE, 63177 Aubière, France \\ ${ }^{4}$ INRA, UMR 1095 UBP, 63100 Clermont-Ferrand, France \\ ${ }^{5}$ Montpellier SupAgro, UMR 1208 IATE, 34060 Montpellier, France \\ * present address: Department of Biological Sciences, Macquarie University, NSW 2109, Australia \\ ** present address: Department of Environmental Sciences, Government College University Faisalabad, \\ 38000-Allama Iqbal Road Faisalabad, Pakistan
}

Correspondence to: S. Fontaine (sebastien.fontaine@clermont.inra.fr)

Received: 31 May 2012 - Published in Biogeosciences Discuss.: 18 July 2012

Revised: 25 January 2013 - Accepted: 27 January 2013 - Published: 21 February 2013

\begin{abstract}
The respiratory release of $\mathrm{CO}_{2}$ from soils is a major determinant of the global carbon cycle. It is traditionally considered that this respiration is an intracellular metabolism consisting of complex biochemical reactions carried out by numerous enzymes and co-factors. Here we show that the endoenzymes released from dead organisms are stabilised in soils and have access to suitable substrates and co-factors to permit function. These enzymes reconstitute an extracellular oxidative metabolism (EXOMET) that may substantially contribute to soil respiration (16 to $48 \%$ of $\mathrm{CO}_{2}$ released from soils in the present study). EXOMET and respiration from living organisms should be considered separately when studying effects of environmental factors on the $\mathrm{C}$ cycle because EXOMET shows specific properties such as resistance to high temperature and toxic compounds.
\end{abstract}

\section{Introduction}

Knowledge of the metabolic pathways through which organic carbon $(\mathrm{C})$ is oxidised into carbon dioxide $\left(\mathrm{CO}_{2}\right)$ in soils is fundamental to understanding the global $\mathrm{C}$ cycle and its interactions with climate (Fontaine et al., 2007; Heimann and Reichstein, 2008). Organic $\mathrm{C}$ is the building block of living organisms and is de facto highly stable in absence of cata- lysts. For instance, the physical oxidation of one molecule of glucose requires a temperature greater than $500^{\circ} \mathrm{C}$. In soils, microorganisms set up a complex cascade of biochemical reactions mediated by numerous enzymes making the oxidisation of organic $\mathrm{C}$ possible at low temperature.

The mineralisation of organic $\mathrm{C}$ requires two main steps. First, microorganisms secrete extracellular enzymes in soil in order to deconstruct plant and microbial cell walls (e.g., endoglucanase), depolymerize macromolecules (e.g., peroxydase), and ultimately produce soluble substrates for microbial assimilation (e.g., glucosidase) (Chróst, 1991; Burns and Dick, 2002; Sinsabaugh et al., 2009). No molecule of $\mathrm{CO}_{2}$ is released during this depolymerization step. The second step of mineralisation, during which $\mathrm{C}$ is released as $\mathrm{CO}_{2}$, implies the absorption and utilisation of solubilized substrates by microbial cells with the aim to produce energy (ATP). In cells, soluble substrates are carried out by a cascade of endoenzymes (enzymes contained by membranes of living cells; Sinsabaugh et al., 2012), along which protons and electrons are transferred from a substrate to an appropriate acceptor (e.g., the aerobic respiration as well as the anaerobic respiration and the fermentation with different final electron acceptors; Prescott et al., 2002). Under aerobic conditions, the oxidative metabolism leads to production of adenosine triphosphate (ATP), consumption of oxygen $\left(\mathrm{O}_{2}\right)$ and emission of 
$\mathrm{CO}_{2}$. Respiration fluxes and ATP production in soils are usually positively correlated with activity of dehydrogenase endoenzymes (e.g., Casida et al., 1964), but only some of them carry a decarboxylase function (e.g., pyruvate dehydrogenase, oxoglutarate dehydrogenase) that cut the carboxyl function of organic $\mathrm{C}$ molecules to liberate $\mathrm{CO}_{2}$.

The function of respiration-carrying endoenzymes depends on various co-factors that must be regenerated (e.g., $\mathrm{NAD}^{+}$), on being located adjacent to other enzymes and on physiological properties of the cell (e.g., redox potential) (Krebs, 1981; Rich, 2003). Given this complexity and the typical fragility of respiratory enzymes, it is traditionally considered that respiration (second step of $\mathrm{C}$ mineralisation process) is strictly an intracellular metabolism process (Burns, 1982; Makoi and Ndakidemi, 2008). Besides, from an evolutionary point of view, soil microorganisms have no interest in provoking extracellular respiration since the energy resulting from this respiration (ATP) may escape from the cell that provided enzymes (Allison et al., 2011). However, some studies have shown that substantial emission of $\mathrm{CO}_{2}$ can persist for several weeks in soils where microbial life has been reduced by exposition to toxics $\left(\mathrm{ClCH}_{3}\right.$, orange acridine) or irradiation to undetectable value (Peterson, 1962; Ramsay and Bawden, 1983; Lensi et al., 1991; Trevors, 1996; Kemmitt et al., 2008). Such emission of $\mathrm{CO}_{2}$ could not be explained by an activity of surviving microbes that would be present in low quantity in soils, unless considering unrealistically high cell respiratory activity. Neither could it be explained by the activity of extracellular enzymes previously secreted by soil microorganisms since these enzymes only solubilize organic $\mathrm{C}$ and do not release $\mathrm{CO}_{2}$. To date, the cause of $\mathrm{CO}_{2}$ emission in soils where microbial life has been minimised seems to be unknown and questions our basic knowledge of biology.

The objective of this study is to understand the cause of $\mathrm{CO}_{2}$ emission in soils where microbial life has been suppressed. We hypothesise that an extracellular oxidative metabolism (EXOMET) can be reconstituted by respiratory endoenzymes released from dead organisms in soils and that this EXOMET can substantially contribute to soil $\mathrm{CO}_{2}$ emission. The manuscript is organised according to four key questions:

1. Can an oxidative metabolism occur in an extracellular context?

2. How long can this EXОMET persist within soil? What is the role of soil particles for EXOMET-carrying enzymes?

3. How much does EXOMET contribute to $\mathrm{CO}_{2}$ emission from living soil?

4. What are the specific properties of EXОмЕт?

First, to assess the possibility of an ExOMET, we incubated a cell-free yeast-extract containing respiratory en- zymes with glucose in sterilised water and soil. The EXOMET induced by the yeast-extract was quantified by measuring $\mathrm{CO}_{2}$ and $\mathrm{O}_{2}$ fluxes in water and soil microcosms. Second, the protective role of soil particles (minerals and humus) for respiratory enzymes was tested by incubating three enzymes involved in glycolysis and the Krebs cycle in five top soils sampled from different regions of the world (Table 1). The third part of the manuscript is devoted to the quantification of EXOMET contribution to the $\mathrm{CO}_{2}$ emissions from five studied soils. This contribution was quantified with a method combining modelling and incubations of sterilised and nonsterilised soils. Finally, we studied some EXOMET properties by incubating soils exposed to high temperature, high pressure and toxic compounds.

\section{Materials and methods}

\subsection{Soil sampling and sterilisation}

For each of the five studied sites (Table 1), twenty independent soil samples were collected from the $0-20 \mathrm{~cm}$ soil layer. Soil samples from each site were pooled to make a composite sample per site. Soil was sieved at $2 \mathrm{~mm}$ and was then used to determine $\mathrm{pH}$, texture and organic matter content and to conduct incubation experiments. The five soils presented textures from sandy-silted to silty-clay soils, $\mathrm{pH}$ ranging from 4.3 to 8.6 and three types of land use (grassland, forest and crops, Table 1). The soil from Theix was used for all investigations, whereas the other soils were used to generalise the key findings of this study.

Some incubation experiments involved the use of sterilised soils. We tested different methods of soil sterilisation $(\gamma-$ irradiation, autoclaving and dry heating) during preliminary investigations. Irradiation was chosen among other sterilising methods for its efficiency to kill soil micro-organisms and for its moderate effect on soil enzymes (see S1 for details of investigations on soil sterilisation). The preservation of soil enzymes was important for quantifying the EXOMET contribution to soil $\mathrm{CO}_{2}$ emissions (see the Sect. 2.4). Soils were sterilised by $\gamma$-irradiation at $45 \mathrm{kGy}\left({ }^{60} \mathrm{Co}\right.$, IonIsos, ISO14001, France).

\subsection{Demonstration of EXOMET by incubating a cell-free yeast-extract in sterilised water and soil}

\subsubsection{Production of cell-free yeast-extract}

Pichia pastoris X33 (Invitrogen, Clare et al., 1991) cells were cultured at $28^{\circ} \mathrm{C}$ in a $1.5 \mathrm{~L}$ capacity Applikon bioreactor containing synthetic medium described by Boze et al. (2001). This medium contained $80 \mu \mathrm{g} \mathrm{L}^{-1}$ D-biotin, $40 \mathrm{~g} \mathrm{~L}^{-1}$ glycerol and mineral solutions (FM21 and PTM1). The $\mathrm{pH}$ of the medium was regulated at 5 using a $\mathrm{NH}_{4} \mathrm{OH}$ solution $(15 \%$, $v / v$ ) that also served as a nitrogen source. Dissolved $\mathrm{O}_{2}$ was measured using a polarographic probe and was maintained at 
Table 1. Site characteristics and soil properties.

\begin{tabular}{llllll}
\hline & \multicolumn{5}{c}{ Sites } \\
\cline { 2 - 6 } & Bugac & Laqueuille & Ponta Grossa & Sor $\varnothing$ & Theix \\
\hline Country & Hungary & France & Brazil & Denmark & France \\
Land use & Grassland & Grassland & Crops & Beech forest & Grassland \\
Clay/Silt/Sand (\%) & $10 / 5 / 85$ & $19 / 55 / 26$ & $14 / 6 / 80$ & $10 / 22 / 68$ & $26 / 25 / 49$ \\
$\mathrm{pH}$ & 8.6 & 5.3 & 7.0 & 4.3 & 6.2 \\
OM content $\left(\mathrm{g} \mathrm{C} \mathrm{kg}^{-1}\right)$ & 44.0 & 121.9 & 14.8 & 33.7 & 39.0 \\
CEC $\left(\mathrm{cmol}+\mathrm{kg}^{-1}\right)$ & 10.2 & 25.1 & 3.9 & 9.5 & 21.5 \\
\hline
\end{tabular}

over $30 \%$ saturation by stirring up to $1800 \mathrm{rpm}$ and aeration (an injection of $1 \mathrm{~L}$ of air per litre of medium per minute). Data acquisition and bioprocess control were carried out using the Applikon biocontroller software. Biomass concentration of culture samples was determined by weighing washed cells after drying at $105^{\circ} \mathrm{C}$ to constant weight.

The yeast culture was harvested at the end of the growth phase by centrifugation at $25000 \times \mathrm{g}$ for $10 \mathrm{~min}$ at $5^{\circ} \mathrm{C}$ to yield a hard pellet. To remove the culture media, the sediment was washed and re-decanted three times in potassium phosphate buffer $(0.1 \mathrm{M}, \mathrm{pH}=6.5$ which corresponded to the $\mathrm{pH}$ of the Theix soil used for the experiment, $\left.V_{\text {yeast }} / V_{\text {buffer }}=1 / 10\right)$. The sediment was resuspended in a small volume of potassium phosphate buffer $\left(V_{\text {yeast }} / V_{\text {buffer }}=2 / 1\right)$ before cells were disrupted with a French pressure cell press (100 MPa, Vanderheiden et al., 1970). Unbroken cells and large cell debris were removed from the yeast extract by fourteen successive centrifugations at $25000 x \mathrm{~g}$ and $5^{\circ} \mathrm{C}$. The yeast extract was filtered under sterile conditions at $0.2 \mu \mathrm{m}$ to obtain a cell-free extract. Direct microscopic observation confirmed sterility of the yeast extract (S1). The cell-free yeast extract was immediately incorporated into water and soil microcosms under sterile conditions. The cell-free yeast extract contained $28.5 \mathrm{mg}$ protein (Biuret method, Okutucu et al., 2007) and 0.77 unit $\mathrm{L}^{-1}$ of malate dehygrogenase (MDH).

\subsubsection{Yeast extract incubation in sterilised water and soil}

The cell-free yeast extract (YE) was incubated in sterilised water $(W)$ or in the irradiated-soil $(S)$ of Theix (Table 1). Experimental microcosms consisted of $5 \mathrm{~mL}$ of cell-free yeast extract and $1 \mathrm{~mL}$ of ${ }^{13} \mathrm{C}$ labelled glucose with or without $20 \mathrm{~g}$ of $\gamma$-irradiated-soil $(S+G+\mathrm{YE}$ and $W+G+\mathrm{YE}$ treatments, respectively) placed in $250 \mathrm{~mL}$ airtight flasks. A second dose of glucose was applied after twenty days of incubation in order to determine the persistence of the EXOMET. Water with glucose and irradiated-soil with or without ${ }^{13} \mathrm{C}$ labelled glucose were incubated as control samples $(W+G, S$ and $S+G$ treatments, respectively). The ${ }^{13} \mathrm{C}$ labelled glucose solution $\left(\delta^{13} \mathrm{C}=3712 \%\right.$ ) contained $60 \mathrm{mg} \mathrm{C}$-glucose $\mathrm{mL}^{-1}$ and was sterilised by filtration at $0.2 \mu \mathrm{m}$. Three replicates per treatment were prepared. Soils were incubated at a water potential of $-100 \mathrm{kPa}$. Water and soil microcosms were incubated at $30^{\circ} \mathrm{C}$ for 53 days. The ExOMET induced by the cell-free yeast extract was quantified by measuring the concentration of $\mathrm{CO}_{2},{ }^{13} \mathrm{CO}_{2}$ and $\mathrm{O}_{2}$ in water and soil microcosms throughout the 53 days of incubation (see Sect. 2.6 for details on flux measurements). All manipulations were done under sterile conditions and the sterility of microcosms was verified after 13 and 53 days of incubation through direct fluorescence microscopic observations and TSA-FISH method (see Supplement S1).

\subsection{Soil stabilisation of oxidative metabolism enzymes}

\subsubsection{Enzyme incubation}

In order to quantify the protective role of soil particles (minerals, humus) for respiratory enzymes, three microbial enzymes involved in glycolysis (GHK: glucose hexokinase EC.2.7.1.1, Sigma-Aldrich ref H4502; G6PI: glucose-6-phosphate isomerase EC.5.3.1.9, SigmaAldrich ref P5381) and the Krebs cycle (MDH: malate dehydrogenase, EC.1.1.1.37, Sigma-Aldrich ref M7032) were separately incubated in the non-irradiated-soil from Theix. A solution with an enzymatic activity of approximately $50 \mathrm{U} \mathrm{L}^{-1}$ was prepared for each enzyme. A volume of $15 \mu \mathrm{L}$ of enzyme solution was incorporated in $80 \mathrm{mg}$ soil (dry mass basis) and incubated at $20^{\circ} \mathrm{C}$ and $-100 \mathrm{kPa}$. Soils without enzyme amendment were also incubated as controls. Two sets of each treatment (controls without enzyme and soils with enzyme) were prepared in order to separately quantify the activity of total, soluble and soil-immobilised enzymes. Immobilised enzymes were assumed to be protected from denaturation and proteolysis (Burns, 1982; Sarkar et al., 1989; Quiquampoix, 2000) and expected to maintain their activity in the long-term ( $>$ ten days). Different independent subsets of soil samples were prepared to measure the activity of enzymes at different times between 20 min and 35 days of enzyme incubation in soils. The protective role of soil on respiratory enzymes was generalised against the four other soils varying in texture and organic matter content by repeating the 
A. Glucose hexokinase (GHK E.C. 2.7.1.1)

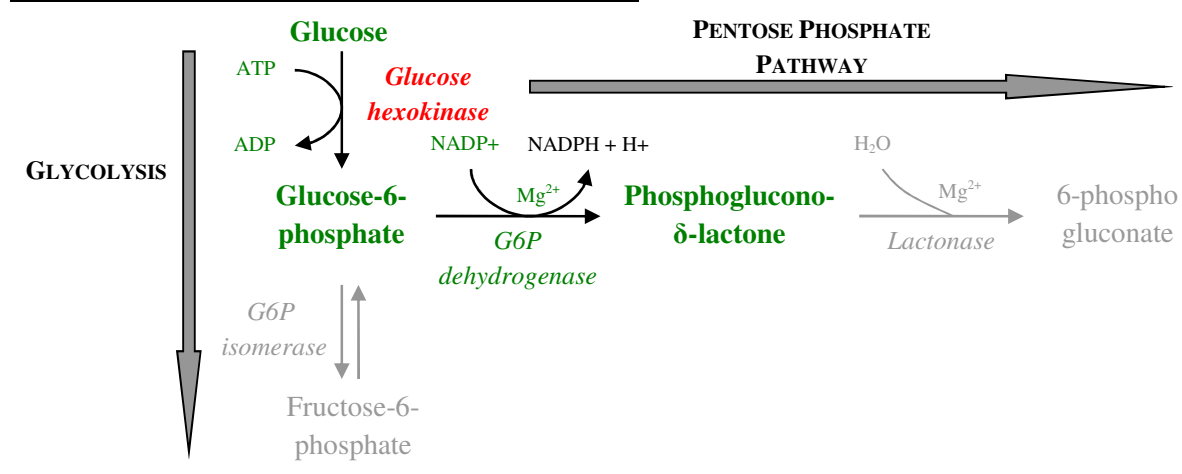

B. Glucose-6-phosphate isomerase (G6PI EC 5.3.1.9)

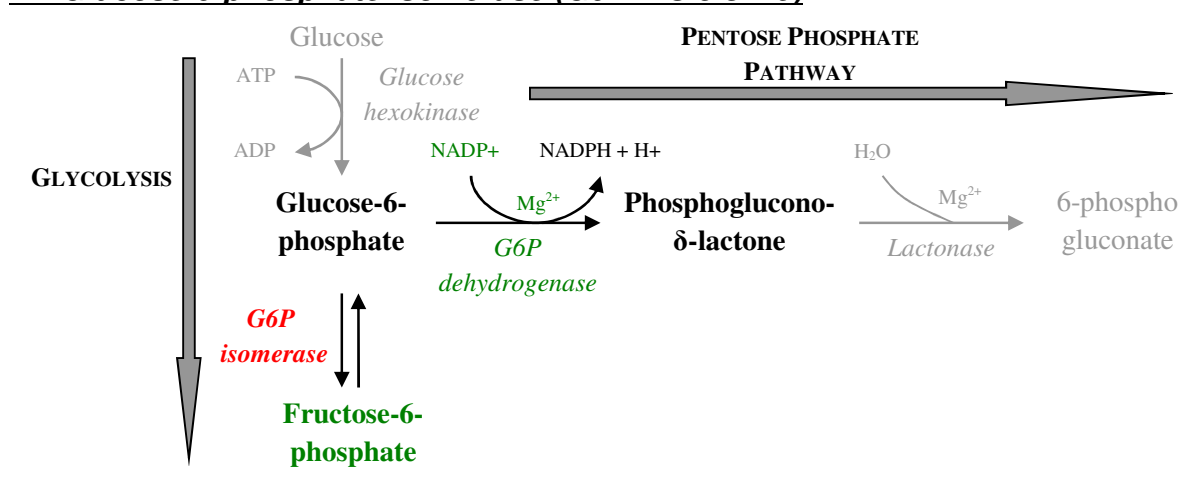

\section{Malate dehydrogenase (MDH EC 1.1.1.37)}

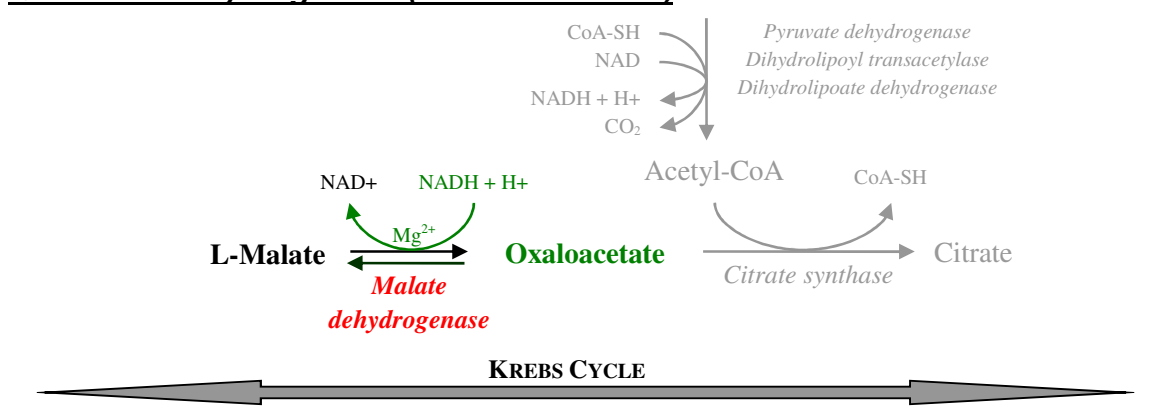

Fig. 1. Enzymatic reactions mediated by the two enzymes involved in glycolysis ((A) GHK: glucose hexokinase, (B) G6PI: glucose-6phosphate isomerase) and the enzyme involved in the Krebs cycle ((C) MDH: malate dehydrogenase) used to quantify the protective role of soil particles on respiratory enzymes. This protective role was studied in the non-irradiated-soil from Theix. The principle of the enzymatic activity measurement was to set up a system of enzymatic reactions where the studied enzyme (red) was the limiting factor. For doing this, we added all substrates, cofactors and intermediary enzymes in excess (green). The activity of the studied enzyme (GHK, G6PI, MDH) was quantified by measuring the formation or the consumption of NADH by spectrometry. Reactions surrounding the studied enzymatic (grey) are given for information.

above experiment and by using the G6PI as a model enzyme (see Supplement S2).

\subsubsection{Principle of enzyme activity measurement}

The principle of the enzymatic activity measurement was to set up a system of enzymatic reactions where the studied enzyme (red in Fig. 1) was the limiting factor (Nardi et al., 2007). To this end, substrates, cofactors and intermediary enzymes of the enzymatic reaction system were mixed in a buffer solution and incorporated in excess in soil samples (green in Fig. 1). The activity of each studied enzyme (GHK, G6PI, MDH) was quantified by measuring the formation or the consumption of NADH by spectrometry following Nardi et al. (2007), with some protocol modifications for soil 
conditions as opposed to leaves. In particular, concentrations of buffer and $\mathrm{Mg}^{++}$solution were increased in order to better control soil $\mathrm{pH}$ and precipitate humic acids that could hamper the quantification of NADPH by spectrometry (both humic acids and NADPH absorb at $340 \mathrm{~nm}$ ). For each of the three enzymes, the enzymatic reaction system and the method of enzyme activity measurement were as follows:

- GHK (Fig. 1a): Soil with or without GHK was amended with $300 \mu \mathrm{L}$ of solution containing a buffer (Bicine$\mathrm{NaOH}, 100 \mathrm{mM}, \mathrm{pH}=8.5)$, glucose $(1.5 \mathrm{mM}), \mathrm{NADP}^{+}$ $(1.5 \mathrm{mM}), \mathrm{Mg}^{++}(32 \mathrm{mM})$ and glucose-6-phosphate dehydrogenase (EC'1.1.1.49, Sigma-Aldrich ref G5885). Production of NADPH following the chemical transformation of glucose in phosphoglucono- $\delta$-lactone was measured by spectrometry at $340 \mathrm{~nm}$.

- G6PI (Fig. 1b): Soil with or without G6PI was amended with $300 \mu \mathrm{L}$ of solution containing a buffer (Bicine$\mathrm{NaOH}, \quad 100 \mathrm{mM}, \quad \mathrm{pH}=8.5$ ), fructose-6-phosphate $(1.5 \mathrm{mM}), \mathrm{NADP}^{+}(1.5 \mathrm{mM}), \mathrm{Mg}^{++}(32 \mathrm{mM})$ and glucose-6-phosphate dehydrogenase $\left(2.5 \mathrm{UL}^{-1}\right)$. Production of NADPH following the chemical transformation of fructose-6-phosphate to phosphoglucono- $\delta$ lactone was measured by spectrometry at $340 \mathrm{~nm}$.

- MDH (Fig. 1c): Soil with or without MDH was amended with $300 \mu \mathrm{L}$ of solution containing a buffer (TRIS $100 \mathrm{mM}, \mathrm{pH}=6.7)$, oxaloacetate $(1.5 \mathrm{mM})$, NADH $(1.5 \mathrm{mM})$ and $\mathrm{Mg}^{++}(32 \mathrm{mM})$. Consumption of NADH following the chemical transformation of oxaloacetate to L-malate was measured by spectrometry at $340 \mathrm{~nm}$.

\subsubsection{Activity of total, soluble and soil-immobilised enzymes}

For each endoenzyme, activity of total, soluble and soilimmobilised enzymes was estimated at different times between 20 min and 35 days of enzyme incubation in soils. At each harvest date, two independent sets of soils were used to quantify activity of total (TotalEnz) and soluble enzymes (SoluEnz). Activity of soil-immobilised enzymes was estimated by difference $(\operatorname{ImmEnz}=$ TotalEnz - SoluEnz). Activity of soluble enzyme (SolEnz) was quantified after their extraction from soil. For extraction, $80 \mathrm{mg}$ soil samples were mixed with the $300 \mu$ of the buffer solution containing substrates, co-factors and intermediate enzymes (see Sect. 2.3.2) and shaken during $5 \mathrm{~min}$. Then, samples were centrifuged at $11000 \mathrm{xg}$ during $3 \mathrm{~min}$. The supernatant containing soluble enzymes, co-factors and substrates was transferred into a micro-plate, where activity of soluble enzyme activity was measured during $3 \mathrm{~min}$. The production rate of NADPH (for GHK and G6PI) and the consumption rate of NADH (for MDH) consecutive to the activity of soluble enzymes were quantified by spectrometry at $340 \mathrm{~nm}$. For measure- ment of total enzyme activity (TotalEnz), the enzymatic reaction was made into the soil in presence of soluble and soilimmobilised enzymes. To this end, soil-enzyme mixture was incubated with substrates and cofactors (see Sect. 2.3.2) during $45 \mathrm{~min}$. At different times between 5 and $45 \mathrm{~min}$ of incubation with substrates, independent samples were harvested and centrifuged at $11000 \times \mathrm{g}$ during $3 \mathrm{~min}$. The NADPH concentration in the supernatant was determined by spectrophotometry at $340 \mathrm{~nm}$. The production of NADPH (for GHK and G6PI) or the consumption of NADH (for MDH) during the $45 \mathrm{~min}$ incubation of soil with substrates corresponded to the activity of total enzymes.

\subsubsection{Kinetic analysis of total enzyme activity}

Different exponential models were tested to fit the decrease in total enzyme activity (Total Enz) with time. The sole exponential model able to explain kinetics of total enzymatic activity considers three pools of enzymes:

$Y(t)=a \cdot \exp (-b \cdot t)+c \cdot \exp (-d \cdot t)+f \cdot \exp (-g \cdot t)$

where $t$ is the time of incubation, $a, c$ and $f$ represent the sizes and $b, d$ and $g$ the decay rates of fast, intermediate and slow pools, respectively. Decay rate of the fast pool was so rapid that it could not be characterised precisely in this experiment. Consequently, size $a$ and decay rate $b$ of the fast pool were fixed to the amount of enzymatic activity lost during the first $20 \mathrm{~min}$ of incubation and to $1 / 5 \mathrm{~min}^{-1}$. Then, parameters $c, d, f$ and $g$ of intermediate and slow pools of enzymes could be estimated using a classical nonlinear regression procedure. We verified that uncertainty on decay rate of the fast pool has negligible effect on estimation of parameters of the intermediate and slow pools. This lack of effect on the estimation of parameters is explained by the strong difference between decay rate of the fast pool and those of intermediate and slow enzyme pools (data not shown). The half-lives of the enzyme pools were calculated as $(\ln 2) /($ decay rate).

\subsection{Contribution of EXOMET to soil respiration}

A method based on the measurement of $\mathrm{CO}_{2}$ emissions from irradiated and non-irradiated soils (see the Sect. 2.4.2) was developed to quantify EXOMET and the respiration of living organisms in the five studied soils. Gamma irradiation, by killing the soil organisms, was considered to stop living respiration whilst preserving soil enzymes (S1) responsible for EХOMET. Therefore, $\mathrm{CO}_{2}$ emissions from irradiated soils were used to estimate the EXOMET. However, $\gamma$-irradiation also released a large quantity of endoenzymes from the killed organisms, thereby artificially increasing the EXOMET in the irradiated-soils. Taking this effect into account, a model of C flux was used to quantify EXOMET and living respiration. 


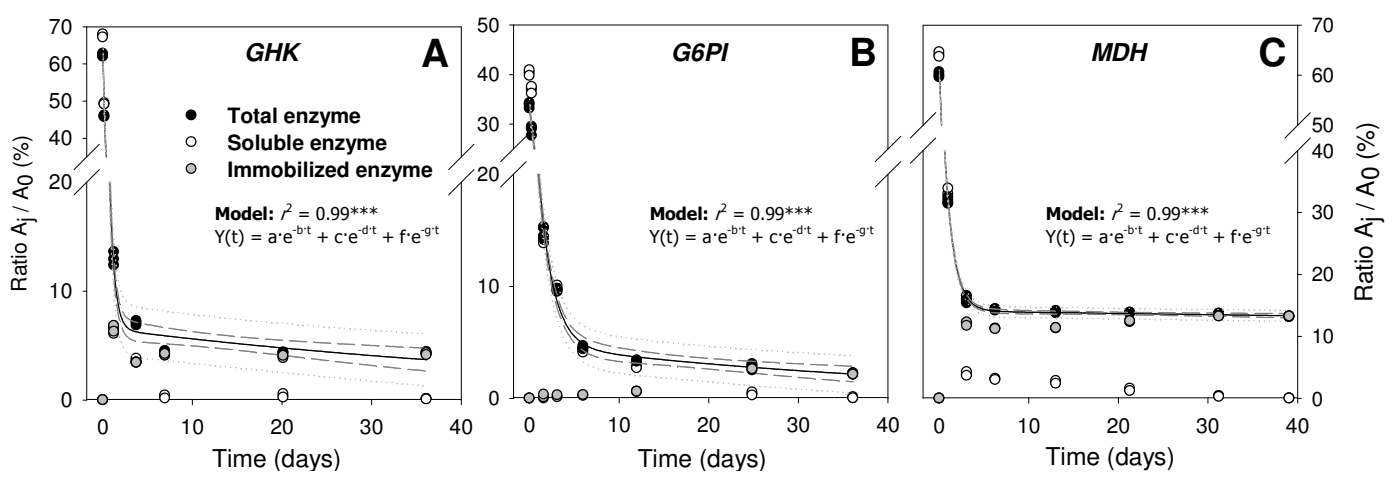

Fig. 2. Activity of three specific enzymes involved in glycolysis and the Krebs cycle following their incorporation in the non-irradiated-soil from Theix. Enzyme activity along time $\left(A_{\mathrm{j}}\right)$ is expressed as \% of the initial activity of enzymatic solution $\left(A_{0}\right)$ applied to the soil. The activities of total (dark circles), soluble (white circles) and immobilised enzymes (grey circles) are distinguished. Full, dashed and dotted lines represent the fit of the kinetic model on total enzyme activity, its confidence and predictive error intervals at $5 \%$ P-level, respectively. (A) G6PI: glucose-6-phosphate isomerase; (B) GHK: glucose hexokinase; (C) MDH: malate dehydrogenase.

\subsubsection{Model of carbon flux}

In the model, $\mathrm{CO}_{2}$ emission from non-irradiated soil $\left(R_{\mathrm{ni}}\right)$ is represented by the sum of living respiration $\left(R_{1}\right)$ and ExOMET $\left(R_{\mathrm{x}}\right)$ (Eq. 2). After irradiation, a fraction $k$ of $R_{1}$ is converted to EXOMET via the soil stabilisation of respiratory enzymes released by the killed organisms. As a result, the sum of EXOMET $\left(R_{\mathrm{X}}\right)$ and $k \cdot R_{1}$ determines $\mathrm{CO}_{2}$ emission from irradiated soil $\left(R_{\mathrm{i}}\right)$ (Eq. 3). The model reads as follows

$R_{\mathrm{ni}}=R_{1}+R_{\mathrm{x}}$

$R_{\mathrm{i}}=k \cdot R_{1}+R_{\mathrm{x}}$

By fixing the same $R_{\mathrm{X}}$ in the irradiated and non-irradiated soils, the model assumes that irradiation has no effect on the pre-existent ExомET $R_{\mathrm{x}}$. We discuss here two examples where irradiation could modify $R_{\mathrm{x}}$. First, the $\gamma$-irradiation by denaturing part of soil enzymes could decrease $R_{\mathrm{x}}$. In this case, it is easy to show that the EXOMET contribution to soil $\mathrm{CO}_{2}$ emissions is underestimated by the model. Nevertheless, this underestimation of EXOMET is likely to be moderate since the effect of $\gamma$-irradiation on soil enzymes is typically low (see review of McNamara et al., 2003). Second, by suppressing the microbial uptake of organic substrates, the irradiation could increase the availability of these substrates for EXOMET increasing $R_{\mathrm{x}}$. In this case, the current model would overestimate the EXОMЕT contribution to soil $\mathrm{CO}_{2}$ emissions. However, EXOMET and living respiration are not likely to be in competition for organic substrates. Indeed, EXOMET may have preferential access to organic substrate since EXOMET-carrying enzymes are adsorbed on soil particles including organic matter. Moreover, most of the soil microsites where EXOMET can proceed are likely to deprived of microorganisms. Indeed, enzymes responsible for EXOMET may diffuse in most soil pores whereas living soil microor- ganisms, due to their size, occupy less than $0.5 \%$ of the soil pore space (Paul and Clark, 1989).

Parameter $k$ varies between $0-1$ and depends on the fraction of respiratory enzymes released by dead organisms that is stabilised in irradiated-soils. In order to estimate $k$, we incubated the glucose-6-phosphate isomerase (G6PI) in the irradiated-soils of Theix, Ponta Grossa, Laqueuille, Sorø and Bugac for 14 days. This enzyme was selected because it showed the smallest stabilised fraction among the three respiratory enzymes tested in the soil from Theix (Fig. 2). The total G6PI activity was measured throughout the incubation as described in the Sect. 2.3.2. For each soil, we fixed the parameter $k$ equal to the fraction of stabilised G6PI activity assuming that the reaction sustained by the G6PI was the limiting reaction for the EXOMET. Other enzymatic reactions could be more limiting for extracellular oxidative metabolism. In this case, $k$ would have a lower value and the calculated ExOMET would increase which would signify that the model underestimates the contribution of the EXOMET to soil $\mathrm{CO}_{2}$ emissions. Moreover, parameter $k$ has a limited bearing on the calculation of EXOMET. For example, for the soil from Theix, we calculated that a $50 \%$ variation of $k$ caused a $6 \%$ deviation in EXOMET.

\subsubsection{Soil incubation experiment}

Experimental microcosms consisted of $30 \mathrm{~g}$ (dry mass basis) samples of fresh sieved soils placed in $250 \mathrm{~mL}$ flask. Sets of irradiated and non-irradiated soils were prepared for the five studied soils. Soils were $\gamma$-irradiated as previously described. Soils were incubated in a dark chamber at $30^{\circ} \mathrm{C}$ and with a water potential of $-100 \mathrm{kPa}$ for 21 days. Sufficient soil microcosms were prepared to permit four destructive harvests and four replicates per treatment. Microcosms were sampled after 2, 6, 13 and 21 days of incubation to quantify $\mathrm{CO}_{2}$ emissions and to verify maintenance of 
irradiated-soils under sterile conditions throughout the incubation. The sterility was verified by a combination of methods including electron microscopy and molecular tracing of functional RNA-producing microorganisms (S1). The C flux model was constrained with $\mathrm{CO}_{2}$ emissions from irradiated $\left(R_{\mathrm{i}}\right)$ and non-irradiated-soils $\left(R_{\mathrm{ni}}\right)$ corresponding to the incubation period 13-21 days. The 0-13 day period was excluded because soil stabilisation of respiratory enzymes required several days (Fig. 2 and S3).

\subsection{Some Exomet properties}

Given that we consider ExOMET to be carried out by soil-protected slow-cycling enzymes rather than microbedependent living respiration with tight physiological constraints, we predicted that EXOMET would show specific properties. First, we suggest that Ехомет persist in the long-term ( $>100$ days) without microbial production of new enzymes. To test this hypothesis, the irradiated soil from Theix was incubated at $30^{\circ} \mathrm{C}$ and with a water potential of $-100 \mathrm{kPa}$ for 332 days. The $\mathrm{CO}_{2}$ emission rate was regularly measured during the incubation period in order to calculate the EXOMET half-life. Second, we suggest that EXOMET resist high temperature, pressure and toxic compounds. To test this hypothesis, we exposed the irradiated-soil from Theix to additional treatments: $150^{\circ} \mathrm{C}$ for two hours, autoclaving $\left(137^{\circ} \mathrm{C}\right.$ and $2.410^{5} \mathrm{~Pa}$ for $45 \mathrm{~min}$ ) or chloroform vapours for $24 \mathrm{~h}$. All microcosms were then incubated at $30^{\circ} \mathrm{C}$ and a water potential of $-100 \mathrm{kPa}$ for 21 days. Four replicates were prepared for each treatment. The $\mathrm{CO}_{2}$ emission from soils exposed to temperature, pressure or toxic compounds were compared to that of control soil (only irradiated) in order to quantify treatments effects on EXOMET.

\subsection{Flux measurements}

In the incubation experiments where gas fluxes were studied (Sects. 2.2, 2.4 and 2.5), two sets of microcosms were prepared in order to quantify gas exchange and to determine the ${ }^{13} \mathrm{C}$ content of released $\mathrm{CO}_{2}$. In one set of microcosms, the released $\mathrm{CO}_{2}$ was trapped in $\mathrm{NaOH}$. The ${ }^{13} \mathrm{C}$ abundance of $\mathrm{CO}_{2}$ was analysed by IRMS after precipitating carbonates with an excess of $\mathrm{BaCl}_{2}$ and filtration. $\mathrm{CO}_{2}$ and $\mathrm{O}_{2}$ gas concentrations in the other set of microcosms were measured by gas spectrometry (Agilent $3000 \mu \mathrm{GC}$, Agilent Technology, Lyon). Concentration of $\mathrm{CO}_{2}$ in atmosphere of flasks was always maintained below $3 \%\left(17 \%\right.$ of $\mathrm{O}_{2}$ in flasks where $\mathrm{CO}_{2}$ was trapped), except at two dates during the yeast extract incubation experiment. In these latter cases, concentration of $\mathrm{CO}_{2}$ reached $4 \%$ (day 10 ) and $22 \%$ (day 0.75 ) signifying the diffusion of $\mathrm{O}_{2}$ may have limited the oxidative metabolism (EXOMET) induced by yeast extract.

\subsection{Data analysis}

All statistical tests were performed with the Statgraphics Plus software (Manugistics, Rockville, MD, USA). General linear model (GLM) procedures, using the LSD method in post ANOVA multiple mean comparison tests, were employed to test effects of soil, treatment (irradiation, substrate and yeastextract amendment, exposure to high temperature, autoclaving and toxic compounds) and time factors on $\mathrm{CO}_{2}$ emission and $\mathrm{O}_{2}$ consumption. When model residuals did not follow a normal distribution, the variables were log-transformed. Nonlinear regressions were used to analyse kinetics of $\mathrm{CO}_{2}$, $\mathrm{O}_{2}$ concentration and enzymatic activity.

\section{Results}

\subsection{Demonstration of EXOMET by incubating a cell-free yeast-extract in sterilised water and soil}

The sterility of microcosms was maintained throughout the experiment (S1). The emission of $\mathrm{CO}_{2}$ was null in water with glucose ( $W+G$, data not shown). Despite sterilisation, soils with and without glucose $(S$ and $S+G)$ still emitted $\mathrm{CO}_{2}$ throughout the incubation (Fig. 3) confirming previous observations (Peterson, 1962; Ramsay and Bawden, 1983; Lensi et al., 1991; Trevors, 1996). The supply of glucose had no effect on soil $\mathrm{CO}_{2}$ emissions ( $S$ versus $S+G)$. In contrast, the combined supply of glucose and cell-free yeast-extract containing respiratory enzymes triggered sudden and enormous respiration fluxes in water and soil ( $W+G+\mathrm{YE}$ and $S+G+\mathrm{YE}$, respectively). The $\mathrm{CO}_{2}$ emission from $W+G+\mathrm{YE}$ and $S+G+\mathrm{YE}$ treatments respectively represented 725 and 72 times that of control soil (after eighteen hours of incubation, Fig. 3). The released $\mathrm{CO}_{2}$ originated from added ${ }^{13} \mathrm{C}$ labelled glucose and unlabelled substrates present in yeast-extract and soil (S4). Moreover, $\mathrm{CO}_{2}$ emissions mirrored the consumption of $\mathrm{O}_{2}$ for all treatments and dates, with the exception of $W+G+\mathrm{YE}$ treatment at eighteen hours of incubation (respiratory quotient $=2$, Fig. 3a). In this particular case, the availability of $\mathrm{O}_{2}$ was reduced, metabolic activity was intense and the pressure in microcosms rose to $1.25 \mathrm{~atm}$, all of which indicated the presence of fermentative metabolism.

Our results confirm the idea that the enzymatic cascade leading to the oxidation of organic $\mathrm{C}$ (i.e., glycolysis and the Krebs cycle) can occur in an extracellular context in soil and water. This indicates that respiratory enzymes can maintain their activity outside the cell and have access to substrate and co-factor flux to function. It is worth noting that the electron transfer to $\mathrm{O}_{2}$ was maintained since the emission of $\mathrm{CO}_{2}$ was coupled to the consumption of $\mathrm{O}_{2}$ (Fig. 3a). This electron transfer, probably carried out by the cytochromes of cellular debris (Trevors et al., 1982), permits the regeneration of electron acceptors (i.e., NAD+) explaining the persistence of 

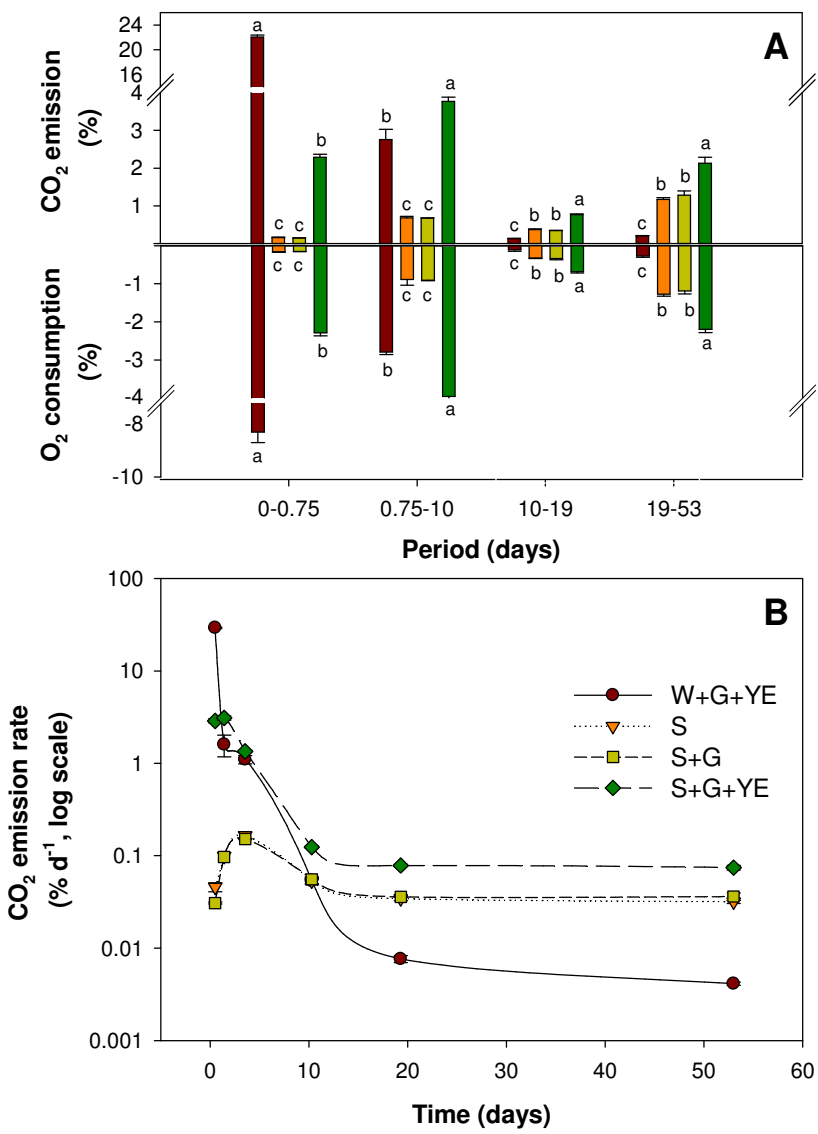

Fig. 3. (A) Total (labelled + unlabelled) $\mathrm{CO}_{2}$ emission and $\mathrm{O}_{2}$ consumption from irradiated-soil $(S)$; irradiated-soil + labelled glucose $(S+G)$; irradiated-soil + labelled glucose + yeastextract $(S+G+$ YE $)$; water + labelled glucose + yeast-extract $(W+G+\mathrm{YE})$ for four periods of incubation. Results are expressed as \% of microcosm atmosphere. Water with labelled glucose was also incubated as control, but $\mathrm{CO}_{2}$ emission from this control was null and not reported. Letters at each sampling date indicate the ANOVA-based differences at $5 \%$ P-level among treatments. (B) Total (labelled + unlabelled) $\mathrm{CO}_{2}$ emission rate from water and soil microcosms. Symbols are the same as Fig. $3 \mathrm{a}$.

EXOMET over 53 days (Fig. 3). Moreover, our results show that fermentative metabolism is another intracellular process that can be reconstituted outside the cell when the availability of $\mathrm{O}_{2}$ for the EXOMET is low.

The EXOMET was significantly higher in water than in soil during the first eighteen hours of incubation $(W+G+$ YE versus $S+G+$ YE, Fig. 3b), which can be explained by enzyme inhibitors present in soil (Burns, 1982). However, EXOMET continuously decreased with time in water whereas it stabilised in soil at a rate representing $247 \%$ of $\mathrm{CO}_{2}$ emissions from sterile control soil at day 20. The higher EХOMET in soil than in water after 20 days (Fig. 3b) cannot be explained by an exhaustion of C-substrate in water since the second glucose dose had no effect (S5). These results indicate that
Table 2. Size and half-time of fast, intermediate and slow pools of respiratory enzymes in the non-irradiated-soil from Theix. GHK: glucose hexokinase, G6PI: glucose-6-phosphate isomerase, $\mathrm{MDH}$ : malate dehydrogenase. Pool size and half-time were obtained by fitting the kinetic model presented in Sect. 2.3 to total enzyme activity (Fig. 2).

\begin{tabular}{lrrrrrr}
\hline \multirow{2}{*}{ Enzyme } & \multicolumn{2}{c}{ Fast pool } & \multicolumn{2}{c}{ Intermediate pool } & \multicolumn{2}{c}{ Slowpool } \\
\cline { 2 - 7 } & $\begin{array}{r}\text { Size } \\
(\%)\end{array}$ & $\begin{array}{r}\text { Half-life } \\
(\min )\end{array}$ & $\begin{array}{r}\text { Size } \\
(\%)\end{array}$ & $\begin{array}{r}\text { Half-life } \\
(\mathrm{h})\end{array}$ & $\begin{array}{r}\text { Size } \\
(\%)\end{array}$ & $\begin{array}{r}\text { Half-life } \\
(\text { days })\end{array}$ \\
\hline GHK & 35.8 & $<14$ & 57.6 & 8.9 & 6.6 & 43.3 \\
G6PI & 66.4 & $<14$ & 28.8 & 26.4 & 4.8 & 31.5 \\
MDH & 38.3 & $<14$ & 47.6 & 17.1 & 14.1 & 495.1 \\
\hline
\end{tabular}

the soil particles permit EXOMET persistence, possibly by preserving the respiratory enzymes from denaturation and proteolysis.

\subsection{Soil stabilisation of oxidative metabolism enzymes}

Kinetic analysis of total enzyme activities indicated the existence of fast-, intermediate- and slow-cycling pools of enzymes in the soil from Theix (Fig. 2, Table 2). Between 36 and $66 \%$ of the initial enzymatic activity was lost within minutes following enzyme addition to the soil (the difference between initial activity and that $20 \mathrm{~min}$ after enzyme addition, Fig. 2). The half-life of this fast pool was too fast to be determined precisely, but is $<14 \mathrm{~min}$ (Table 2). Given the rapidity of their inactivation, enzymes of the fast-cycling pool were likely denatured by physico-chemical processes (Burns, 1982). A second pool of enzymes representing $29-58 \%$ of the initial activity was inactivated more slowly with a halflife of 9-26h. Soil proteolytic activity may have contributed to the degradation of this pool (Sarkar et al., 1989). Finally, $5-14 \%$ of the initial enzymatic activity was retained in a highly stable form with a half-life of 32-495 days. Figure 2 shows that this long-term persistence of enzymatic activities exclusively relied on enzymes immobilised on soil particles (humus and minerals). These results confirm the protective role of soil particles for respiratory enzymes against physicochemical denaturation and proteolysis. Our investigations in the other soils gave consistent results with $0.8-3.3 \%$ of the initial enzymatic activity stabilised (S2).

\subsection{Contribution of EXOMET to soil respiration}

Despite sterilisation by $\gamma$-irradiation, the five studied soils released large quantities of $\mathrm{CO}_{2}$ throughout the incubation period (Fig. 4). After 21 days of incubation, cumulated $\mathrm{CO}_{2}$ emissions from the irradiated-soil represented 17 to $59 \%$ of that measured in non-irradiated-soil depending on soil type (Fig. 4). The value of model parameter $k$ was determined for the soils of Theix, Ponta Grossa and Laqueuille, but not for the soils of Sorø and Bugac where large releases of humic acids did not permit the measurement of G6PI activity 
Table 3. Activity of glucose-6-phosphate isomerase (G6PI) and model quantification of $\mathrm{CO}_{2}$ emissions from living organisms $\left(R_{1}\right)$ and extracellular oxidative metabolism $\left(R_{\mathrm{X}}\right)$ for the five studied soils. $R_{\mathrm{ni}}$ and $R_{\mathrm{i}}$ represent $\mathrm{CO}_{2}$ emissions from non-irradiated and irradiated soil, respectively, for the incubation period 13-21 days. $k$ is the fraction of $R_{1}$ converted in extracellular oxidative metabolism (EXOMET) after irradiation. Contribution (\%) of EXOMET to soil $\mathrm{CO}_{2}$ emission was calculated as $R_{\mathrm{X}} / R_{\mathrm{ni}} \cdot 100$. nd $=$ not determined

\begin{tabular}{|c|c|c|c|c|c|}
\hline \multirow[b]{2}{*}{ G6PI activity (\% initial activity) } & \multicolumn{5}{|c|}{ Sites } \\
\hline & Bugac & Laqueuille & Ponta Grossa & Sorø & Theix \\
\hline 7 days & nd & $0.5 \pm 0.05$ & $5.1 \pm 0.4$ & nd & $10.5 \pm 0.9$ \\
\hline 14 days & nd & $0.3 \pm 0.03$ & $3.1 \pm 0.1$ & nd & $10.0 \pm 0.4$ \\
\hline \multicolumn{6}{|c|}{ Model quantification of the two metabolic pathways of organic $\mathrm{C}$ oxidation } \\
\hline \multicolumn{6}{|l|}{ Model inputs } \\
\hline$R_{\mathrm{ni}}\left(\mathrm{mg} \mathrm{C}-\mathrm{CO}_{2} \mathrm{~kg}^{-1}\right)$ & $168.8 \pm 2.6$ & $186.4 \pm 3.3$ & $162.8 \pm 0.9$ & $200.2 \pm 1.5$ & $56.4 \pm 0.5$ \\
\hline$R_{\mathrm{i}}\left(\mathrm{mg} \mathrm{C}-\mathrm{CO}_{2} \mathrm{~kg}^{-1}\right)$ & $98.2 \pm 3.2$ & $40.3 \pm 1.5$ & $30.6 \pm 0.8$ & $34.6 \pm 0.9$ & $30.2 \pm 0.9$ \\
\hline$k(\%)$ & nd & $0.3 \pm 0.03$ & $3.1 \pm 0.1$ & nd & $10.0 \pm 0.4$ \\
\hline \multicolumn{6}{|l|}{ Model results } \\
\hline$R_{1}\left(\mathrm{mg} \mathrm{C}-\mathrm{CO}_{2} \mathrm{~kg}^{-1}\right)$ & nd & 146.5 & 136.4 & nd & 29.1 \\
\hline$R_{\mathrm{X}}\left(\mathrm{mg} \mathrm{C}-\mathrm{CO}_{2} \mathrm{~kg}^{-1}\right)$ & nd & 39.9 & 26.4 & nd & 27.3 \\
\hline $\begin{array}{l}\text { Contribution of the extracellular oxidative } \\
\left.\text { metabolism to } \mathrm{CO}_{2} \text { emission ( } \%\right)\end{array}$ & nd & 21.3 & 16.2 & nd & 48.4 \\
\hline
\end{tabular}

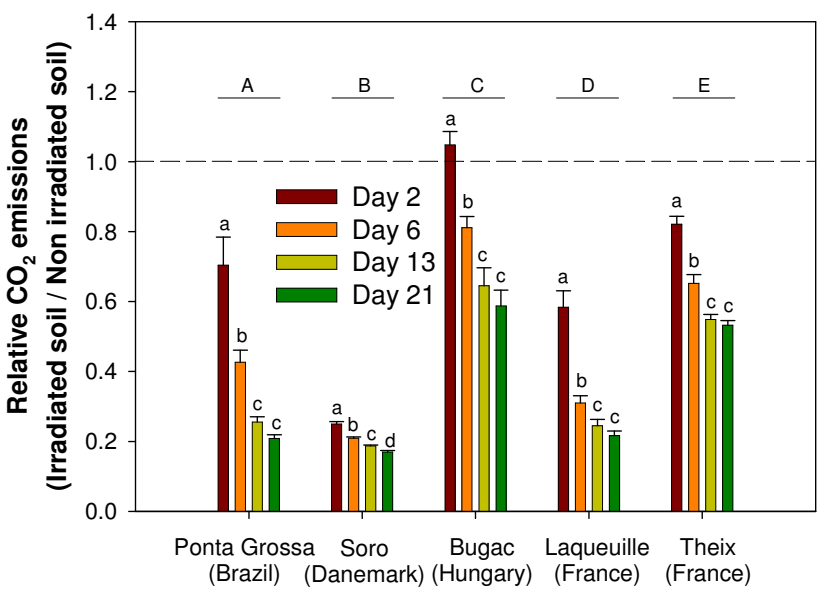

Fig. 4. Relative $\mathrm{CO}_{2}$ emission between irradiated and nonirradiated soil for the five studied soils. Day 2, Day 6, Day 13 and Day 21 represent days of incubation. Letters indicate the differences at $5 \%$ level between measurements over time (lower case) and across soils (upper case) based on repeated-measures analysis of variance.

(Table 3 and S3). For the three soils where $k$ could be determined, modelling results indicated that EXOMET substantially contributed to $\mathrm{CO}_{2}$ emissions from the non-irradiatedsoils (Table 3). EXOMET was responsible for 16, 21 and $48 \%$ of $\mathrm{CO}_{2}$ emissions from the soils of Ponta Grossa, Laqueuille and Theix, respectively. These unexpected contributions of EXOMET indicate the presence of a large quantity of respiratory enzymes in soils outside cells.

\subsection{Some ExомeT properties}

Significant $\mathrm{CO}_{2}$ emissions were maintained throughout the 332 day incubation of irradiated-soil from Theix (Fig. 5). We calculated that the half-life of ExOMET was 165 days. This result confirms the idea that EXOMET can persist in the longterm without microbial production of new enzymes. This persistence reflects soil stabilisation of respiratory enzymes released by ancient generations of microbial populations.

Although the treatments applied to the irradiated-soil from Theix (high temperature, pressure and chloroform) are known to denature unprotected enzymes and be lethal for most microorganisms (Koffler et al., 1957; Kashefi and Lovley, 2003; Rainey et al., 2005; Lopez-Garcia, 2007), significant $\mathrm{CO}_{2}$ emissions persisted during the 21 day incubation period. Based on soil $\mathrm{CO}_{2}$ emissions (Fig. 6), we estimated that 50,20 and $10 \%$ of EXOMET were resistant to chloroform, $150^{\circ} \mathrm{C}$ and autoclaving, respectively. Thus, soil particles not only protect enzymes against denaturation (e.g., Lähdesmäki and Pnspanen, 1992), but also allow the maintenance of complex oxidative metabolism in conditions where life is generally impossible.

\section{Discussion and perspectives}

Our findings show that complex biochemical reactions underpinning respiration can occur in the soil without compartmented living structure. Our results also shed light on the key roles of soil particles (minerals, soil organic matter) implied in this phenomenon. Enzymes involved in cell oxidative metabolism can maintain their activity outside the cell thanks 


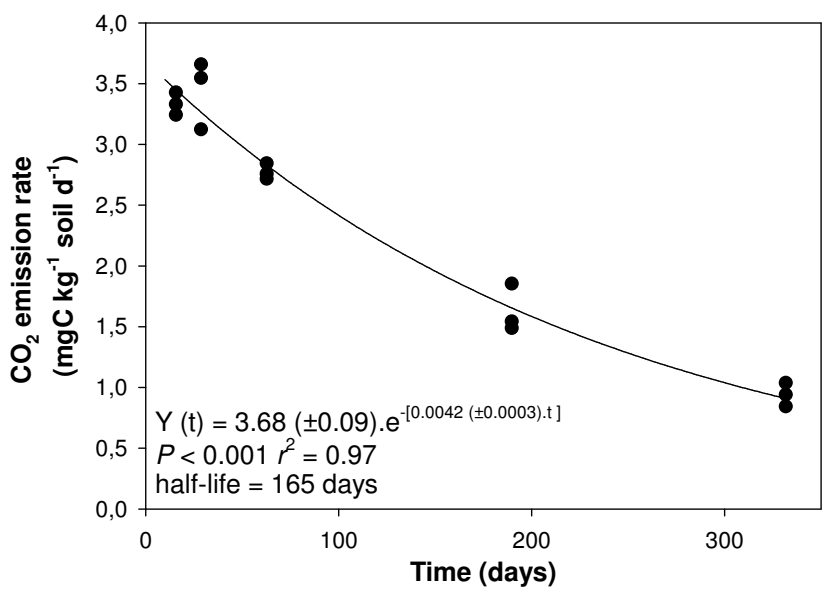

Fig. 5. $\mathrm{CO}_{2}$ emission rate from the irradiated-soil from Theix incubated during 238 days. Half-life $\left(t_{1 / 2}\right)$ was calculated from a simple exponential model.

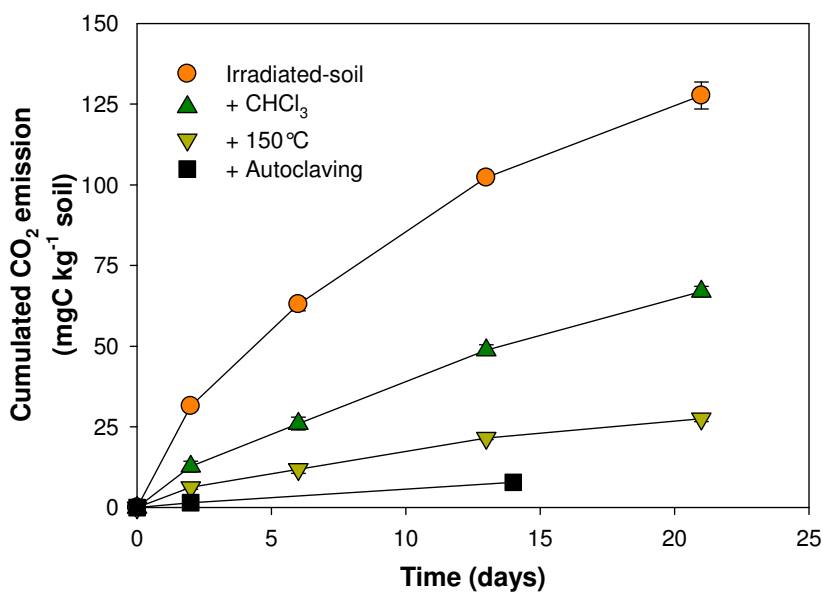

Fig. 6. Cumulated $\mathrm{CO}_{2}$ emission from the soil from Theix after exposure to irradiation (Irradiated-soil), irradiation and $150^{\circ} \mathrm{C}$ $\left(+150^{\circ} \mathrm{C}\right)$, irradiation and chloroform fumigation $\left(+\mathrm{CHCl}_{3}\right)$, and irradiation and autoclaving (+Autoclaving).

to the protective role of soil particles. The concentration of endoenzymes around soil particles may facilitate exchanges of co-substrates and co-factors between enzymes, which are necessary for the cascade of reactions implied in oxidative metabolism. At the end of the respiratory chain, the transfer of electrons to $\mathrm{O}_{2}$ may be carried out by soil particles due to their electric charge (Trevors et al., 1982).

Our results suggest that the EXOMET can substantially (16-48\%) contribute to soil $\mathrm{CO}_{2}$ emissions. This unexpected contribution of EXOMET suggests the presence of a large quantity of respiratory enzymes in soils outside cells. This enzymatic pool may result from the long-term accumulation of enzymes released from dead organisms and stabilised on soil particles (Fig. 2). Thus, $\mathrm{CO}_{2}$ emissions from soils are apparently driven by two major oxidative metabolisms: (1) the well-known respiration of soil biota, (2) an EXOMET carried out by enzymes released from dead organisms and stabilised by soil particles. These key results deserve further experiments that will verify assumptions of our model designed to quantify the EXOMET or ideally will propose an alternative independent method for this quantification.

Living respiration and EXOMET should be considered separately when studying effects of environmental factors on the $\mathrm{C}$ cycle because they do not likely obey to the same laws and respond differently to environmental factors. Soil microorganisms have tight physiological constraints comprising specific environmental conditions (temperature, moisture, absence of toxic compounds) and needs in energy and nutrients. These needs explain why soil $\mathrm{CO}_{2}$ emissions are controlled by the availability of fresh energy-rich $\mathrm{C}$ and nutrients to soil microorganisms (Fontaine et al., 2003; Blagodatskaya et al., 2007; Pascault et al., 2013). In contrast, the ExOMETcarrying enzymes have few physiological constraints and are highly resistant to toxics, high temperature and pressure due to their protection by soil particles (section Sect. 3.4). This EXOMET can explain why part of soil $\mathrm{CO}_{2}$ emissions is independent of microbial biomass size, community structure or specific activity (Kemmitt et al., 2008) and is resistant to toxic compounds and extreme environments (chloroform, high temperature, pressure, and irradiation) (Peterson, 1962; Ramsay and Bawden, 1983; Lensi et al., 1991; Trevors, 1996; Kemmitt et al., 2008). Moreover, the ExOMET could explain the flush of $\mathrm{CO}_{2}$ emission from soils submitted to freezethaw or wet-dry cycles since these treatments promote microbial death and release of respiratory enzymes in soils (Henry, 2007; Borken and Matzner, 2009; Kim et al., 2012). Finally, the long-term persistence of EXOMET-carrying enzymes (Figs. 2 and 5) signifies that current $\mathrm{CO}_{2}$ emissions from soils partly depend on past microbial activities. This memory of soils suggests a delay between the modification of microbial activities and its consequence on soil respiration. Such a delay must be taken into account when studying effects of environmental factors on soil respiration to avoid an underestimation of modification of soil functioning.

The contribution of EXOMET to $\mathrm{CO}_{2}$ emissions was contrasted among the three soils (Table 3), suggesting an important role of soil properties and land use on the balance between living respiration and ExOMET. However, the number of tested soils is too low to draw definitive conclusions and we can only speculate on some factors that could control the ExомET. It is interesting to note that the highest EXOMET contribution to $\mathrm{CO}_{2}$ emissions was found in the soil presenting the highest clay content and the highest capacity to stabilise the endoenzyme G6PI activity (soil from Theix, Tables 1 and 3). The high specific area and electric charge of clay particles may promote stabilisation of endoenzymes on clay surface. The organic-rich soil from Laqueuille has an intermediate position in the ranking of soils according to EXOMET contribution. This soil curiously presents the lowest ability to stabilise the endoenzyme G6PI activity 
(Table 3) despite the fact that it contains clay in proportion comparable to the soil from Theix and large amounts of organic matter that can stabilise enzymes (Burns, 1982; Sarkar et al., 1989). However, the low $\mathrm{pH}$ of this soil (pH 5.3, Table 1) likely reduces the activity of G6PI since this enzyme (like all those of glycolysis) requires alkaline conditions to function. Thus, the capacity of soil particles to promote an EXOMET may not only rely on their ability to protect enzymes, but also on the specific physico-chemical requirements (e.g., pH) of each enzyme. This idea is supported by results from our incubation of three different endoenzymes in the soil from Theix. In this acid soil $(\mathrm{pH}=6.2)$, the proportion of stabilised enzyme activity was twice as high in the MDH case (pH optimal =6.7) compared to the G6PI and GHK cases ( $\mathrm{pH}$ optimal $=8.5$ ) (Fig. 2).

Further experiments are necessary to better understand the molecular mechanisms at play and predict the EXOMET across soils. Processes leading to microbial death and release of endoenzymes in soils (virus infection, predation, cell death due to stress like drought) must be identified. In marine and freshwater ecosystems, viral infection of microbial cells may be an important way by which endoenzymes are released in the environment since between 10 and $40 \%$ of bacterial cells are lysed by viruses (see the review Weinbauer, 2004; Colombet et al., 2006). To our knowledge, such quantification does not exist for terrestrial ecosystems. The endoenzymes stabilised by soil particles (humus, minerals) could be identified by soil proteomics (Wallenstein et al., 2008) whereas the chain of biochemical reactions involved in EXOMET could be precisely characterised by metabolomics (Baudoin et al., 2001; Wallenstein et al., 2008, 2010). Further experiments should also explore possible interactions between cellular respiration and EXOMET, such as the competition for soluble substrate use. Nevertheless, the EXOMET is likely to be common in many soil types as consistent results were found in the five contrasted studied soils. Moreover, the reconstitution of intracellular metabolism outside the cell could occur in other environments (sediments, water) and may concern other metabolisms (methanisation, denitrification) since it should only require the presence of dead cells releasing endoenzymes. We, therefore, encourage research in other environments to quantify the role of intracellular metabolisms reconstituted outside the cell on global C cycle.

\section{Supplementary material related to this article is available online at: http://www.biogeosciences.net/10/ 1155/2013/bg-10-1155-2013-supplement.pdf.}

Acknowledgements. We thank D. Tourvieille and the "Plant and Pathogen" team of the UMR-INRA 1095 for their technical support. We thank P. Ambus, L. da Silveira Pontes, and L. Horváth who sampled the soil in Denmark, Brazil and Hungary, respectively; C. Mallet for culture analysis; S. Revaillot, O. Delfosse and J.-L. Ollier for chemical and isotopic analyses; L. Genestoux, C. Chabalier, F.-X. Sauvage, N. Duchatau for respiratory enzyme activity analyses, G. Borrel for gas spectrometry; A. Eller, S. Grootemaat, J. Bloor for the revision of English; and V. Allard, P. Barré, S. Barot, R. Pilon, J. Bloor, M. Bahn, M. Wallenstein, $\AA$. Blagodatskaya and the two other anonymous referees for their constructive comments on previous versions of the manuscript. The research leading to these results received funding from the French Institutes INRA-INRIA (ARC-VitelBio), the French national agency ANR (DIMIMOS), le Conseil Général d'Auvergne (CPER 2007-2013) and the European Community's 6th and 7th Framework Programmes (FP6 and FP7) under grant agreement no. 017841 (Nitro-Europe) and no. 226701 (CARBO-Extreme). All authors have refused to apply for the research bonus scheme set up by the French government in 2010 and have consequently no competing financial interest in this work. This work is dedicated to Waniya Shahzad and Gabin Maire.

Author contributions: This work originated from an idea of SF; VM, GA, ED and SF designed experiments; RD and MJ conducted soil incubations and counting of cultivable microorganisms; JC conducted electron microscopic observations of soils, ACL, RD, VM and SF performed gas spectrometry; ACL and VM performed fluorescence in situ hybridisation (TSA-FISH); VM and SF conducted the incubation experiment with endoenzymes; GA, VP, ED and SF conducted the incubation experiment with yeast-extract; SF built the model for estimating EXOMET in soils; VM, GA, TS and SF wrote the manuscript; and all authors took part in the interpretation of the results.

Edited by: M. Bahn

\section{References}

Allison, S. D., Weintraub, M. N., Gartner, T. B., and Waldrop, M. P.: Evolutionary economic principles as regulators of soil enzyme production and ecosystem function, edited by: Shukla, G. and Varma, A., Soil Enzymology, Springer-Verlag, Berlin, Germany, 229-243, 2011.

Baudoin, E., Benizri, E., and Guckert, A.: Metabolic fingerprint of microbial communities from distinct maize rhizosphere compartments, Eur. J. Soil Biol., 37, 35-93, 2001.

Blagodatskaya, E. V., Blagodatsky, S. A., Anderson, T. H., and Kuzyakov, Y.: Priming effects in Chernozem induced by glucose and $\mathrm{N}$ in relation to microbial growth strategies, Appl. Soil Ecol., 37, 95-105, 2007.

Borken, W. and Matzner, E.: Reappraisal of drying and wetting effects on $\mathrm{C}$ and $\mathrm{N}$ mineralization and fluxes in soils, Glob. Change Biol., 15, 808-824, 2009.

Boze, H., Laborde, C., Chemardin, P., Richard, F., Venturing, C., Combarnous, Y., and Moulin, G.: High-level secretory production of recombinant porcine follicle-stimulating hormone by Pichia pastoris, Process Biochem., 36, 907-913, 2001. 
Burns, R. G.: Enzyme-activity in soil - location and a possible role in microbial ecology, Soil Biol. Biochem., 14, 423-427, 1982.

Burns, R. G. and Dick, R. P.: Enzymes in the Environment: Activity, Ecology and Applications, Books in Soils, Plants, and the Environment Series, 86, CRC Press, 2002.

Casida, L. E., Klein, D. A., and Sartoro, T.: Soil dehydrogenase activity, Soil Sci., 98, 371-376, 1964.

Chróst, R. J.: Microbial Enzymes in Aquatic Environments, Brock Springer, Contemporary Bioscience Series, London, 1991.

Clare, J. J., Rayment, F. B., Ballantine, S. P., Sreekrishna, K., and Romanos, M. A.: High-level expression of tetanus toxin fragment $\mathrm{c}$ in Pichia pastoris strains containing multiple tandem integrations of the gene, Bio/Tech., 9, 455-460, 1991.

Colombet, J., Sime-Ngando, T., Cauchie, H. M., Fonty, G., Hoffmann, L., and Demeure, G.: Depth-related gradients of viral activity in lake Pavin, Appl. Environ. Microb., 72, 4440-4445, 2006.

Fontaine, S., Mariotti, A., and Abbadie, L.: The priming effect of organic matter: A question of microbial competition?, Soil Biol. Biochem., 35, 837-843, 2003.

Fontaine, S., Barot, S., Barre, P., Bdioui, N., Mary, B., and Rumpel, C.: Stability of organic carbon in deep soil layers controlled by fresh carbon supply, Nature, 450, 277-280, 2007.

Heimann, M. and Reichstein, M.: Terrestrial ecosystem carbon dynamics and climate feedbacks, Nature, 451, 289-292, 2008.

Henry, H. A. L.: Soil freeze-thaw cycle experiments: trends, methodological weakness and suggested improvements, Soil Biol. Biochem., 39, 977-986, 2007.

Kashefi, K. and Lovley, D. R.: Extending the upper temperature limit for Life, Science, 301, p. 934, 2003.

Kemmitt, S. J., Lanyon, C. V., Waite, I. S., Wen, Q., Addiscott, T. M., Bird, N. R. A., O’Donnell, A. G., and Brookes, P. C.: Mineralization of native soil organic matter is not regulated by the size, activity or composition of the soil microbial biomass-a new perspective, Soil Biol. Biochem., 40, 61-73, 2008.

Kim, D.-G., Vargas, R., Bond-Lamberty, B., and Turetsky, M. R.: Effects of soil rewetting and thawing on soil gas fluxes: a review of current literature and suggestions for future research, Biogeosciences, 9, 2459-2483, doi:10.5194/bg-9-2459-2012, 2012.

Koffler, H., Mallett, G. E., and Adye, J.: Molecular basis of biological stability to high temperatures, P. Natl. Acad. Sci. USA, 43, 464-477, 1957.

Krebs, H.: Introductory remarks, Philos. T. Roy. Soc. B, 293, 3-4, 1981.

Lähdesmäki, P. and Pnspanen, R.: Soil enzymology: Role of protective colloid systems in the preservation of exoenzyme activities in soil, Soil Biol. Biochem., 24, 1173-1177, 1992.

Lensi, R., Lescure, C., Steinberg, C., Savoie, J. M., and Faurie, G.: Dynamics of residual enzyme-activities, denitrification potential, and physicochemical properties in a gamma-sterilised soil, Soil Biol. Biochem., 23, 367-373, 1991.

Lopez-Garcia, P.: Habitability: the point of view of a biologist, in: Lectures in Astrobiology, edited by: Gargaud, M., Martin, H., and Claeys, P., Adv. Astrobio. Biogeo., Springer-Verlag Berlin, Berlin, 2, 221-237, 2007.

Makoi, J. H. R. and Ndakidem, P. A.: Selected soil enzymes: example of their potential roles in the ecosystem, Afr. J. Biotechnol., 7, 181-191, 2008.
McNamara, N. P., Black, H. I. J., Beresford, N. A., and Parekh, N. R.: Effects of acute gamma irradiation on chemical, physical and biological properties of soils, Appl. Soil Ecol., 24, 117-132, 2003.

Nardi, S., Muscolo, A., Vaccaro, S., Baiano, S., Spaccini, R., and Piccolo, A.: Relationship between molecular characteristics of soil humic fractions and glycolytic pathway and krebs cycle in maize seedlings, Soil Biol. Biochem., 39, 3138-3146, 2007.

Okutucu, B., Dincer, A., Habib, O., and Zihnioglu, F.: Comparison of five methods for determination of total plasma protein concentration, J. Biochem. Bioph. Meth., 70, 709-711, 2007.

Pascault, N., Ranjard, L., Kaisermann, A., Bachar, D., Christen, R., Terrat, S., Mathieu, O., Lévêque, J., Mougel, C., Henault, C, Lemanceau, P., Péan, M., Boiry, S., Fontaine, S., and Maron, P.-A.: Stimulation of different functional groups of bacteria by various plant residues as a driver of soil priming effect, Ecosystems, in press, 2013.

Paul, E. A. and Clark, F. E.: Soil Microbiology and Biochemistry. Academic Press Inc., San Diego, CA., USA, 273 pp., 1989.

Peterson, G. H.: Respiration of soil sterilized by ionizing radiations, Soil Sci., 94, 71-74, 1962.

Prescott, L., Harley, J., and Klein, D.: Microbiology, McGraw-Hill Compagnies, New York, 2002.

Quiquampoix, H.: Mechanisms of protein adsorption on surfaces and consequences for extracellular enzyme activity in soil, in: Soil Biochem., edited by: Bollag, J.-M. and Stotzky, G., Marcel Dekker, New York, 10, 171-206, 2000.

Rainey, F. A., Ray, K., Ferreira, M., Gatz, B. Z., Nobre, M. F., Bagaley, D., Rash, B. A., Park, M. J., Earl, A. M., Shank, N. C., Small, A. M., Henk, M. C., Battista, J. R., Kampfer, P., and da Costa, M. S.: Extensive diversity of ionizing-radiation-resistant bacteria recovered from Sonoran Desert soil and description of nine new species of the genus Deinococcus obtained from a single soil sample, Appl. Environ. Microb., 71, 5225-5235, 2005.

Ramsay, A. J. and Bawden, A. D.: Effects of sterilization and storage on respiration, nitrogen status and direct counts of soil bacteria using acridine-orange, Soil Biol. Biochem., 15, 263-268, 1983.

Rich, P. R.: The molecular machinery of Keilin's respiratory chain, Biochem. Soc. T., 31, 1095-1105, 2003.

Sarkar, J. M., Leonowicz, A., and Bollag, J. M.: Immobilization of enzymes on clays and soils, Soil Biol. Biochem., 21, 223-230, 1989.

Sinsabaugh, R. L., Hill, B. H., and Follstad Shah, J. J.: Ecoenzymatic stoichiometry of microbial organic nutrient acquisition in soil and sediment, Nature, 462, 795-798, 2009.

Sinsabaugh, R. L. and Follstad Shah, J. J.: Ecoenzymatic stoichiometry and ecological theory, Annual Review of Ecology, Evolution, and Systematics, Annu. Rev. Ecol., 43, 313-343, 2012.

Trevors, J. T.: Sterilization and inhibition of microbial activity in soil, J. Microbiol. Meth., 26, 53-59, 1996.

Trevors, J. T., Mayfield, C. I., and Inniss, W. E.: Measurement of electron-transport system (Ets) activity in soil, Microb. Ecol., 8, 163-168, 1982.

Vanderheiden, G. J., Fairchild, A. C., and Jago, G. R.: Construction of a laboratory press for use with the French pressure cell, Appl. Microbiol. 19, 875-877, 1970.

Wallenstein, M. D. and Weintraub, M. N.: Emerging tools for measuring and modelling the in situ activity of soil extracellular en- 
zymes, Soil Biol. Biochem., 40, 2098-2106, 2008.

Wallenstein, M. D., Hess, A. M., Lewis, M. R., Steltzer, H., and Ayres, E.: Decomposition of aspen leaf litter results in unique metabolomes when decomposed under different tree species, Soil Biol. Biochem, 42, 484-490, 2010.
Weinbauer, M. G.: Ecology of prokaryotic viruses, FEMS Microbiol. Rev., 28, 127-181, 2004. 